\title{
A scoping review of home-produced heroin and amphetamine-type stimulant substitutes: implications for prevention, treatment, and policy
}

\author{
Evelyn Hearne ${ }^{1 *}$, Jean-Paul Cornelius Grund ${ }^{2,3,4}$, Marie Claire Van Hout ${ }^{1}$ and Jim McVeigh ${ }^{5}$
}

\begin{abstract}
Several home-produced substances such as krokodil and boltushka are prevalent in many Eastern European countries. Anecdotal reports of its use have been circulating in Germany and Norway; however, this has not been confirmed. Its use has also been reported by the media in the USA, although only one confirmed report of its use exists. Home-produced drugs are associated with high levels of morbidity and a number of complex health issues such as the spread of blood borne viruses, gangrene, and internal organ damage. The high incidence of HIV rates amongst people who inject home-produced substances is a public health concern. The resulting physical health consequences of injecting these crude substances are very severe in comparison to heroin or amphetamine acquired in black markets. Due to this fact and the increased mortality associated with these substances, professionals in the area of prevention, treatment, and policy development need to be cognisant of the presentation, harms, and the dangers associated with home-produced substances globally. This scoping review aimed to examine existing literature on the subject of home-produced heroin and amphetamine-type stimulant substitutes. The review discussed the many implications such research may have in the areas of policy and practice. Data were gathered through the use of qualitative secondary resources such as journal articles, reports, reviews, case studies, and media reports. The home production of these substances relies on the utilisation of precursor drugs such as less potent stimulants, tranquillizers, analgesics, and sedatives or natural plant ingredients. The Internet underpins the facilitation of this practice as recipes, and diverted pharmaceutical sales are available widely online, and currently, ease of access to the Internet is evident worldwide. This review highlights the necessity of prevention, education, and also harm reduction related to home-produced drugs and also recommends consistent monitoring of online drug fora, online drug marketplaces, and unregulated pharmacies.
\end{abstract}

Keywords: Homemade drugs, Scoping studies, Krokodil, Internet, Kitchen chemistry

\section{Background}

The use of drugs in countries of the former socialist republic is not a recent phenomenon [1, 2]. Following the Former Soviet Union's (fSU) downfall in December 1991, with the addition of massive social and economic collapse in Eastern Europe, came the escalating problem of illicit drug use [1-4] especially in Russia, the Ukraine, the Baltic States, and most other former Soviet republics

\footnotetext{
* Correspondence: ehearne@wit.ie

${ }^{1}$ School of Health Sciences, Waterford Institute of Technology, Waterford, Ireland

Full list of author information is available at the end of the article
}

[1, 2, 5-10]. Indeed, homemade drug cultures emerged already in the $\mathrm{FSU}$ in the late 1970s and 1980s, as well as in, Czechoslovakia, Poland, and Hungary [1, 11, 12]. Monetary restrictions and closed borders that preluded the Soviet Union's downfall prohibited individuals from acquiring the substances emerging in the counter cultures of Western Europe and the USA [1, 2]. As a result, all the countries emerging from the Soviet Union have a shared history of widespread homemade drug use, primarily opiates and amphetamine-type stimulants (ATS), through the usage of natural elements, diverted pharmaceutical drugs, and even household chemicals $[4,13,14]$. 
A foremost concern for public health and drug policy is the diversion and misuse of pharmaceuticals [15]. The Internet underpins this concern as both recipes of drug chemistry and diverted pharmaceuticals are available online and the Internet is now accessible to virtually anyone worldwide [16]. United Nations Office on Drugs and Crime (UNODC) reported an increase in the diversion of pharmaceuticals for non-medicinal use in many countries including Nigeria, the USA, Hong Kong, Sweden, Australia, Canada, Indonesia, Germany, and China $[16,17]$.

There are a substantial number of physical harms resulting from injecting homemade drug solutions and countless dangers connected to the practice of home cooking of heroin and ATS substitutes such as the spread of blood borne viruses (BBVs), skin and soft tissue infections, and even chemical injuries and burns as a result of explosions during the cooking process [14, 18-23]. Cooks and consumers alike are exposed to these chemicals, as are potentially their families and the environment [24, 25]. Further research in this area will be of great benefit to healthcare workers, treatment providers, and policy makers. As the consequences of injecting these homemade substances are considerably more acute than existing illicit narcotics [26], and life expectancy lower [19], treatment providers globally should be cognisant of the dangers of, presentation, and harms related to homemade drug use. Policy makers should be responsive, as homemade drug use in countries outside of Eastern Europe may be probable for reasons such as the current global economic climate and the effects of resulting austerity measures on vulnerable communities such as heroin users in Greece turning to cheap homemade methamphetamine; mephedrone and MDPV taking over people who inject drugs (PWID) scenes in Romania; and effortless access to unregulated pharmacies and online drug markets [16]. By scoping the literature, healthcare workers and treatment providers will benefit, and highlighted gaps in current research should inform practice and policymakers. An incidence of this type of drug production may be detrimental to PWID and become a major public health concern. This scoping study will focus on the history of homemade drug use worldwide but particularly in Eastern Europe, as it is more prevalent there. The harms associated with the practice of producing and consuming homemade drugs will be highlighted for harm reduction purposes and aimed toward prevention, treatment, and policy.

\section{The scoping review}

Scoping studies are gradually being encouraged for the extensive searching of literature on specific subjects. They are primarily used to emphasise the gaps and key issues in the current evidence base and to find areas that require further research, practical, and policy interventions $[15,27-29]$. It is important to acknowledge the limitations of a scoping study. As the quantity of data generated in a scoping study is sometimes considerable, the decision to include all material available versus a more detailed analysis of a smaller number of studies can be difficult. Scoping studies do not appraise the evidence quality in the primary research papers, and as a result, scoping studies simply offer a descriptive or narrative interpretation of available research $[16,27]$. This scoping review employed qualitative secondary sources together with peer reviewed journal articles, reports, reviews, case studies, and some media accounts. A thorough list using many different search terms was used to perform a literature search. These terms included "homemade drugs", "kitchen chemistry", "krokodil", "desomorphine", "boltushka", "drug formulation tampering", and "online drug markets". To guarantee all articles relevant to the study were included, a broad search was conducted using many databases: EBSCO Host, Science Direct, PubMed, PsycINFO, and MEDLINE. A set of criteria for inclusion and exclusion in the study were put in place. Inclusion criteria consisted of home-produced substances limited to ATS and heroin substitutes and full-text access. Exclusion criteria consisted of incomprehensible language, animal studies, and insignificance to the scoping review (see Fig. 1 and Table 1).

\section{Heroin and amphetamine-type stimulants}

Heroin addiction is defined as a chronic relapsing condition that, for many, is an unrelenting, lifelong illness with severe effects. This is particularly relative to short life expectancies and high rates of morbidity [30-33]. Ninety percent of the world's heroin supply is directly from opium grown in Afghanistan. Heroin that is produced from Afghan poppies is shipped worldwide [34]. With an estimated 3.1 million consumers, Europe is the main destination for Afghan heroin. In Europe, the Russian Federation is by far the largest consumer of Afghan heroin [34] with $2.3 \%$ of its population injecting opioid drugs, indicative of Russia's proximity to Afghanistan [23]. Approximately 1.5 million people consume heroin in the Russian Federation and 1.6 million dispersed over other European countries [34].

The most widespread used opiate worldwide is Codeine, an alkaloid prepared from opium via a process known as methylation [35-37]. Codeine is employed in several different ways such as a sedative, analgesics, treatment of tuberculosis, and anti-diarrhoeal $[36,38]$. In recent years, codeine-containing cough syrups (CCS) have been seen as independent substances of abuse and moreover as substitution for conventional drugs of abuse, e.g. amphetamines, cocaine, and opiates [37, 39, 40]. Combination analgesics containing codeine (CACCs) are a mixture of codeine and 


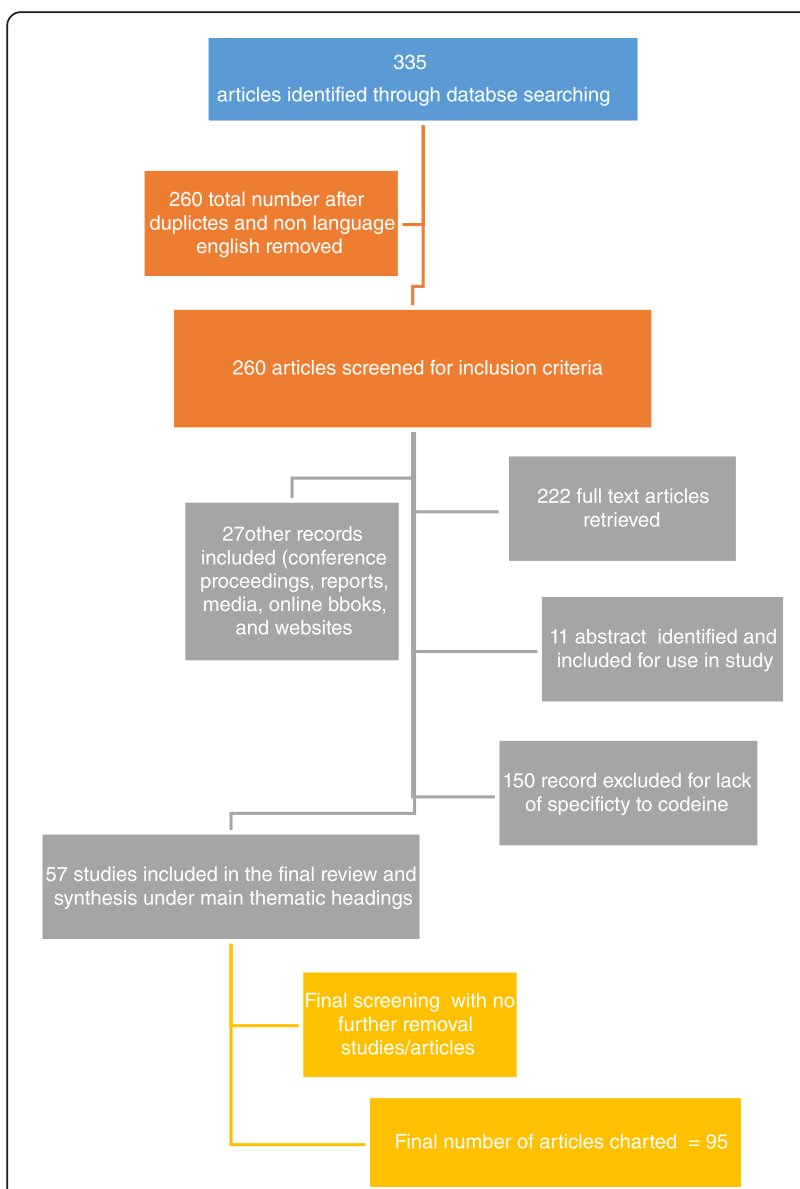

Fig. 1 Flow diagram charting inclusion and exclusion criteria for this study

other substances, e.g. ibuprofen, paracetamol, or aspirin. CACCs are obtainable over-the-counter (OTC) drugs in some countries worldwide such as Ireland (Solpadeine ${ }^{\oplus}$ ), Australia (Panadeine ${ }^{\oplus}$ ), and the Ukraine (Codelac ${ }^{\bullet}$ and Terpincod ${ }^{\circledR}$. These sales of CACCs were banned in Russia in June 2012 [22]; however, codeine has simply moved to the black market and is therefore still available. CACCs bought over the counter are considered "safe" to treat pain, if used in accordance with the recommended dosages. Yet, persistent long-term use and unnecessary dosing patterns can result in dependence physically and psychologically;

Table 1 Categories used to organise the literature

Homemade drug use in Eastern Europe

Homemade drug use outside of Eastern Europe

Heroin and amphetamine-type stimulants/substitutes

Harms associated with homemade drugs

Drug and formulation tampering

The Internet

Scoping studies continual headaches as a result of overuse of the medication; and a myriad of other complex medical issues [41, 42].

Amphetamine-type stimulants (ATS) include amphetamine, d-amphetamine, methamphetamine, methylphenidate, 3,4-methylenedioxymethamphetamine (MDMA) and also cathinone, methcathinone, pseudoephedrine, fenetylline, and ephedrine [43-45]. These are a sizeable collection of psychoactive compounds that all contain natural elements in their chemical structure [45]. ATS operate on a person's nervous system and have powerful effects on the individual's mind and body. Some of these include appetite suppression, heart rate elevation, intense happiness, and mental and energy awareness. Although ATS are characteristically controlled substances, a number of them are regulated and utilised for treating disorders such as attention deficit hyperactivity disorder (ADHD), narcolepsy, and depression that is resistant to treatment [46]. There currently stands a general nonmedicinal use of such stimulants $[45,47]$ with ATS production and manufacture occurring in numerous parts of the world [48]. Indeed, ATS use is more prevalent than cocaine or opiates [49]. It is suggested that there are 35 million people using ATS worldwide, compared with 29 million people consuming opiate and/or cocaine $[34,48,50]$. There are several variations in the form of ATS produced globally, e.g. in Europe, ATS manufacture is primarily in tablet or powder forms of ecstasy (MDMA) and amphetamine. In the Czech Republic and other countries of Central and Eastern Europe, homemade methamphetamine is locally known as "Pervitin", "Vint", or "Shirka" [1, 2, 51].

\section{History of homemade drug use}

Throughout the 1970s, information on Western youth and counter culture increasingly triggered the interest in psychoactive drugs amongst young adolescents. The practice of home-cooked drugs most likely commenced 10 to 15 years before the political changes, on the fringes of dissident intellectual "third culture" or "underground" circles. The growing aversion of the stifling Soviet ideology made these young people equally distrustful and disdainful of the harsh Soviet anti-drug propaganda-often phrased in the antiWestern Agit-Prop discourse and images they were subjected to. Keen on emulating the experiences of their western peers, Soviet Youth took their parents' tradition of Samogon to the next level $[1,2]$ and used precursor drugs from natural plant ingredients or over-the-counter or prescription drugs with psychoactive properties-containing less potent stimulants, tranquillizers, analgesics, and sedatives-to produce their own drugs $[1,10,14,19,20,52]$.

In Poland, students from the University of Gdansk (the birthplace of the Solidarity movement) reportedly 
first synthesised "kompot," homemade heroin, by extracting the opioids from poppy straw and acetylation of the morphine content [11, 53]. In early 1980s Prague, "Freud" had taken a few chemistry courses at a technical university before he first synthesised the (in)famous "pervitin" or "piko" (methamphetamine) from ephedrine, the active ingredient in over-the-counter cold medications [54]. Both drugs rapidly diffused amongst young people in both countries in the 1990s. Kompot was the driving force behind the 1980s HIV epidemic amongst PWID in Poland [5]. Although the Czech Republic has been spared widespread HIV infection amongst PWID, pervitin remains the problem child on the Czech drug scene $[1,54,55]$.

During the 1980s these recipes diffused across most Soviet countries, but much less in its Central European vassal states. With that came adjustments of formulae and chemicals used in the synthesis [44], leading to a simpler, cruder process and a range of monikers. Heroin made from poppies became known under the moniker of "cheornaya" (black, referring to the colour of the final liquid drug) and "hanka" in Russia and "shirka" in Ukraine.

Homemade methamphetamine became "vint" in Russian and methcathinone "jeff", or "mulka", while in Ukrainian, these drugs were termed "belyi" and "ephedrone", while cathinone is termed "Bolthuska"3 [1, 44]. This argot is often very local and remarkably elastic. In some Russian towns, methamphetamine was called belyi/beloye and vint in many places in Ukraine. The word belyi is also used for ephedrine or methcathinone or may refer to any stimulants (white for stimulants; black for opiates).
Both the home-produced opioids and ATS are produced using caustic chemicals, such as sulphuric acid (H2SO4), phosphorus, iodine, and industrial or household solvents by (often unskilled) cooks under the most primitive laboratory conditions-in kitchens and basements. It should not come as a surprise that much of these corrosive reactants remain present in the final drug [44]. The grave and harsh reality of this practice is that the substances finally produced come primarily in liquid form, ready for injection, which is the usual mode of use in the region [7].

The phenomenon of homemade drug use continues to influence Eastern European drug culture (see Fig. 2) [53]. Early 2011 saw a remarkable escalation in the number of reports in the media of the use of a new homemade drug known as "krokodil" (Russian: крокодил), also "Russian Magic", "crocodile", or by its chemical name "Desomorphine" $[19,20]$. Research has shown that this home-produced opiate first appeared in Russia around 2002/2003 [19, 20, 23], although Czech drug cooks also modestly produced a drug from codeine based analgesics in the 1980s, known as "braun" or "brown" due to its colour $[1,2]$ (see Table 2) [16].

Desomorphine's sedative properties are ten times stronger than the effects of heroin. However, it has a shorter half-life; therefore, dependence may rapidly appear with continued administration $[19,20]$. There are both serious short- and long-term negative health consequences and high mortality rates associated with krokodil, primarily resulting from the crude desomorphine extraction and the failure to separate or filter out its numerous toxic by-products [19, 20,56-58]. Evidence of widespread use of an injectable home-produced cathinone

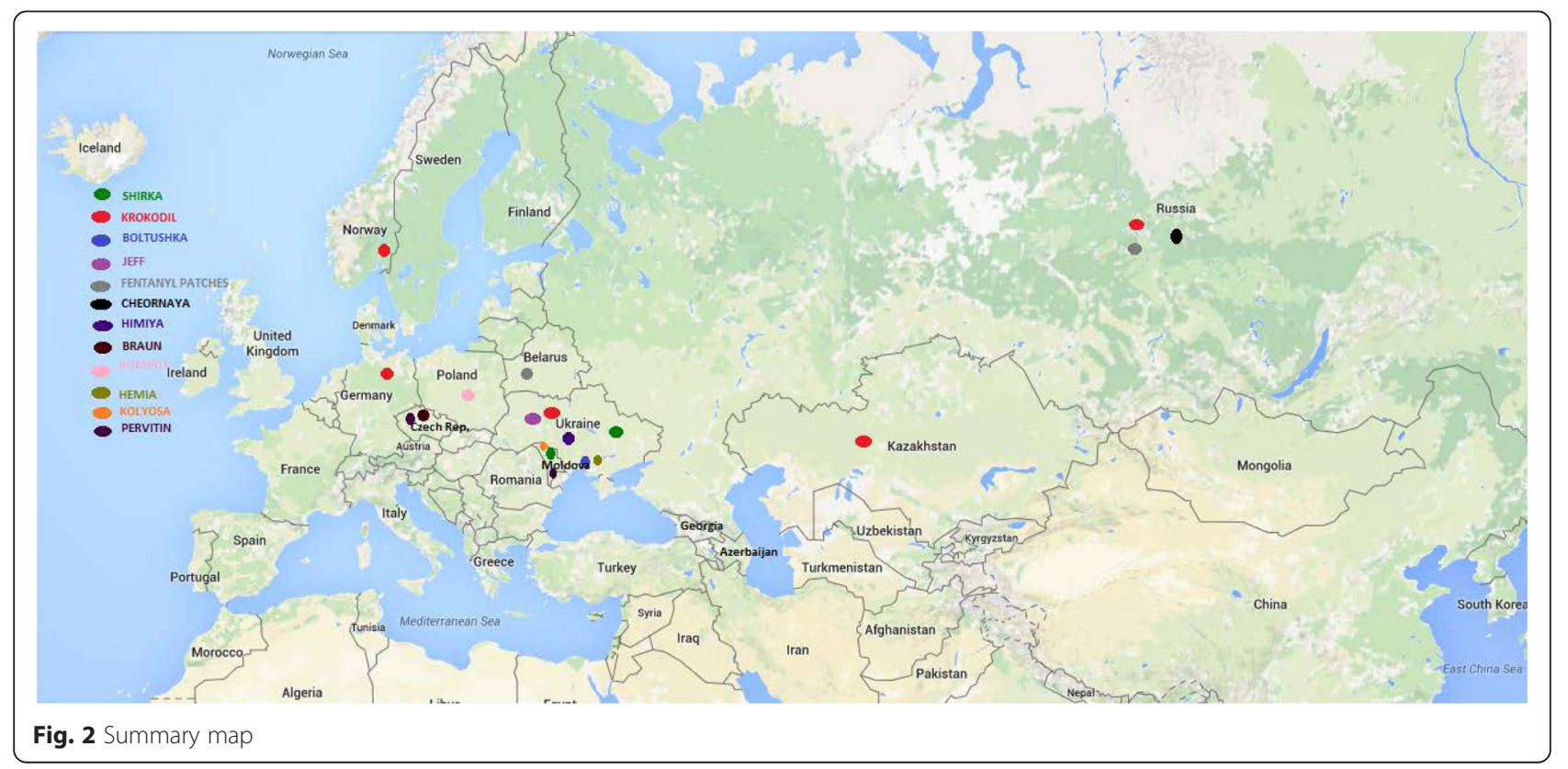


Table 2 Homemade drug solutions, street names, ingredients, geographic area of use and key public health concerns

\begin{tabular}{|c|c|c|c|c|}
\hline Street name & Drug type/chemical & Ingredients & Key adverse health and social consequences & Country/city of use \\
\hline $\begin{array}{l}\text { Krokodil. } \\
\text { Other common } \\
\text { street names: } \\
\text { Russian Magic, } \\
\text { Crocodile, } \\
\text { Russian Heroin }\end{array}$ & $\begin{array}{l}\text { Opiate- } \\
\text { desomorphine }\end{array}$ & $\begin{array}{l}\text { Codeine, gasoline or } \\
\text { paint thinner, iodine, } \\
\text { red phosphorous, } \\
\text { tropicamide }\end{array}$ & $\begin{array}{l}\text { Injecting risks for BBV transmission and risks present } \\
\text { in the production process, contamination, chemical } \\
\text { reaction, sharing of paraphernalia, and group injecting } \\
\text { practices. } \\
\text { High mortality rates. } \\
\text { Krokodil users presenting in surgeries/emergency rooms } \\
\text { with serious and advanced medical complications. } \\
\text { Undesirable medical and social costs. }\end{array}$ & $\begin{array}{l}\text { Russia, Ukraine, Georgia, } \\
\text { Kazakhstan. Germany } \\
\text { (Bochum, Berlin, Frankfurt), } \\
\text { Norway (Tromsø). } \\
\text { Also: } \\
\text { Anecdotal reports in UK, } \\
\text { Czech Republic, France, } \\
\text { Belgium }\end{array}$ \\
\hline Boltushka. & Cathinone & Ephedrine, & Injecting risks for BBV transmission and risks present & Odessa* \\
\hline
\end{tabular}

\section{Other common}

street names:

Baltushka, Balka

Jeff

Other common

street names:

Jaff, Cat, Mulka,

Ephedrone

Fentanyl patches

(new and used).

Other common

street names:

China White,

White Persian

Cheornaya

Opiate

Himiya

Braun

Other common

street name:

Brown

Kompot

Other common

street names:

Polish heroin

Shirka (Ukraine)

Other common

street names:

Cherniashka,

Black, Hanka

Opiate

Opiate

Opiate pseudoephedrine, warm water household vinegar, and potassium permanganate

Methcathinone

Phenylpropanolamine, warm water, household vinegar, and potassium permanganate

Fentanyl, acetaminophen, caffeine

Poppy Straw, cigarette ash sodium bicarbonate

Poppy straw

acetic anhydride,
acetone

Mixture of morphine and codeine products, e.g. hydrocodone

in the production process, contamination, chemical reaction, sharing of paraphernalia, and group injecting practices.

Long-term users of boltushka can experience partial loss of cognitive function, Alzheimer-type symptoms, and possible brain damage.

Manganese-induced Parkinsonism, which is irreversible. Undesirable medical and social costs.

Injecting risks for BBV transmission and risks present in the production process, contamination, chemical reaction, sharing of paraphernalia, and group injecting practices.

Manganese-induced Parkinsonism.

Injecting risks for BBV transmission.

Undesirable medical and social costs.

Fentanyl use is associated with increased odds of overdose.

Criminality such as misusers who resort to obtaining used patches from elderly nursing home residents, and searching hospital and nursing home dumpsters for discarded patches.

Undesirable medical and social costs.

Access to poppy straw is seasonal and when it is scarce, injectors will turn to other opiate-type drugs. Injecting risks for BBV transmission and risks present in the production process, contamination, chemical reaction, sharing of paraphernalia, and group injecting practices.

Circulatory damage and soft tissue infections amongst injectors.

Undesirable medical and social costs.

Access to poppy straw is seasonal and when it is scarce, injectors will turn to other opiate-type drugs, including krokodil.

Injecting risks for BBV transmission and risks

present in group injecting practices.

Undesirable medical and social costs.

Injecting risks for BBV transmission and risks present in the production process, contamination, sharing of paraphernalia, and group injecting practices.

Access to poppy straw is seasonal and when it is scarce, injectors will turn to other opiate-type drugs. Injecting risks for BBV transmission

Guillain-Barré Syndrome.

Injecting risks for BBV transmission and risks present in group injecting practices. Undesirable medical and social costs.

Opiate Poppy straw

Access to poppy straw is seasonal and when it is scarce, injectors will turn to other opiate-type drugs Injecting risks for BBV transmission and risks present in group injecting practices.

Undesirable medical and social costs.
Ukraine

Russia, Belarus

Russia

Ukraine

Czech Republic

Poland

Ukraine, Moldova 
Table 2 Homemade drug solutions, street names, ingredients, geographic area of use and key public health concerns (Continued)

\begin{tabular}{|c|c|c|c|c|}
\hline Shirka (Odessa*) & Methamphetamine & $\begin{array}{l}\text { Ephedrin, } \\
\text { Pseudoephedrine }\end{array}$ & $\begin{array}{l}\text { Binge-using patterns that enhance the probability } \\
\text { of unintentional overdoses. } \\
\text { Injecting risks for BBV transmission, i.e. risks present } \\
\text { in the production process, contamination, sharing } \\
\text { of paraphernalia, and group injecting practices. } \\
\text { Undesirable medical and social costs. }\end{array}$ & Odessa* \\
\hline Hemia & Opiate & Poppy straw & $\begin{array}{l}\text { Access to poppy straw is seasonal and when it is } \\
\text { scarce, injectors will turn to other opiate-type drugs, } \\
\text { including krokodil and kolyosa. } \\
\text { Injecting risks for BBV transmission and risks present } \\
\text { in group injecting practices. } \\
\text { Undesirable medical and social costs. }\end{array}$ & Odessa* \\
\hline Kolyosa & Opiate & $\begin{array}{l}\text { Mixture of codeine- } \\
\text { containing pills }\end{array}$ & $\begin{array}{l}\text { Users will turn to this due to poppy straw being } \\
\text { unavailable with associated overdose and injecting risks. } \\
\text { Injecting risks for BBV transmission and risks present } \\
\text { in the production process, contamination, sharing } \\
\text { of paraphernalia, and group injecting practices. } \\
\text { Undesirable medical and social costs. }\end{array}$ & Moldova \\
\hline $\begin{array}{l}\text { Pervitin } \\
\text { Other common } \\
\text { street name: } \\
\text { Vint, Piko }\end{array}$ & Methamphetamine & $\begin{array}{l}\text { Ephedrine, } \\
\text { pseudoephedrine, } \\
\text { industrial chemicals } \\
\text { such as gasoline, } \\
\text { toluene and } \\
\text { tetrachlorethylene }\end{array}$ & $\begin{array}{l}\text { Binge-using patterns that enhance the probability of } \\
\text { unintentional overdoses. } \\
\text { Injecting risks for BBV transmission and risks present } \\
\text { in the production process, contamination, sharing of } \\
\text { paraphernalia, and group injecting practices. } \\
\text { Undesirable medical and social costs. }\end{array}$ & Czech Republic, Moldova \\
\hline
\end{tabular}

* Ukraine - refers to all cities in Ukraine, except Odessa, which has a range of different terms/names for their homemade drugs

known as "boltushka" was noted by Chintalova-Dallas et al. [44]. This ATS was initially reported in Odessa, Ukraine in 2005. Boltushka is produced by mixing vinegar, warm water, potassium permanganate $(\mathrm{KMnO} 4)$ together with the precursor, phenylpropanolamine (PPA) from crushed "koldack" or "teffedrin" tablets [44, 59-61]. The tradition of home-produced drugs has been reported in several other countries such as Norway [14, 62, 63], Georgia, Ukraine, Kazakhstan [14, 23, 64], New Zealand [65], and Germany [14, 63, 66] where the use of krokodil is reported [16]. Greece reported a homemade version of methamphetamine called "shisa" or "drug of the poor" [67, 68], while in the Netherlands and other European Countries, the use of homemade gammahydroxybutyric acid (GHB) is a small but intensive problem [69, 70]. Reports indicate that the occurrence of homemade drug use has transpired as a result of reduced heroin availability in Russia, the Baltic States, and the five central Asian countries [16, 22, 55, 71-73].

\section{Drug and formulation tampering and the Internet}

Using illicit drugs has now been exceeded by the nonmedicinal use and abuse of diverted pharmaceuticals in the USA [13, 74]. (Pseudo) Ephedrine, codeine, codeine cough syrups (CCS), and fentanyl patches are the most ordinarily tampered with pharmaceuticals. Lankenau et al. [75] suggest that formulation tampering with these drugs allows for dispensing higher doses and therefore is cost effective. Motivations for tampering with pharmaceuticals involve numerous reasons including increasing the bio-availability of the drug, quicker onset of the effects, and to boost the drugs psychoactive effects [16]. Sedatives, stimulants, analgesics, and tranquillizers are broadly pursued, measured, and tampered with for the purpose of recreational intoxication $[13,76]$. The Internet is accessible to many people worldwide and is a prime source of information for recreational drug consumers, interested in tampering with formulations due to the wealth of information on websites, including drug user fora, providing potential home cooks with advice and tips on the techniques and recipes. This is a concern for public health, given the pervasive nature of the Internet worldwide $[13,16]$. Previous successes as well as failures are documented and discussed (see www.erowid. org; www.bluelight.ru; www.drugs-forum.com) [13, 77]. Advice includes description of methods for tampering such as crushing, separating, purifying, and optimum usage [13, 78-83]. Moreover, online market places found on the "deep web" or "darknet" are now accessible. The deep web is described as the section of the Internet that is not searchable with established search engines, e.g. google. The darknet is described as a small area within the deep web and has been purposefully concealed and cannot be accessed via usual web browsers [84]. The most well-known online market is the Silk Road Marketplace which was active between Feb 2011 and October 2013, and was followed by Silk Road 2.0 active from November 2013 to November 2014 [85]. Although Silk Road and Silk Road 2.0 have been shut down, other online marketplaces can be found on the "deep web" where the site owners, buyers, and vendors can stay somewhat anonymous due to their IP addresses being 
masked and random routing via peer-based computer networks, using the TOR browser [85-87]. These online marketplaces are innovative new avenues for drug sales [88, 89, 90, 91], facilitating anonymous acquisition and supply of licit drugs, pharmaceuticals, and illicit drugs alike [91]. Additionally, the Internet hosts a number of drug discussion fora, wherein users publicly and anonymously exchange knowledge. Several Darknet drug markets have discussion fora as well, where, for example, the quality of the drugs and vendors are rated and discussed. These drug fora offer users practical tools prior to purchase and use of substances and indigenous harm reduction. Numerous studies have emphasised the importance of harm reduction occurring amongst these online communities [92-96]. Between 2010 and 2012, Russian policy makers highlighted the negative effect the Internet had in the dissemination of information related to krokodil production and use. A marked rise in online searches for krokodil preparation and methods to purchase was noted [16]. However, a major reduction in Internet searches for krokodil related information was noted after the ban on pharmaceutical sales of codeine, June 1, 2012 [22].

\section{Harms associated with homemade drug use: implications for harm reduction}

The well-established tradition of "kitchen chemistry" [16] is still dominating stimulant and opioid use in many parts of Eastern and Central Europe [23]. These homemade drugs are rife in marginalised strata of society such as amongst people with lower socioeconomic status or homeless individuals, due to their low costs and widespread availability of OTC or diverted pharmaceuticals and easy access to recipes [16, 23, 97]. In Russia, the process for producing krokodil only comprises of a small amount of precursor pharmaceuticals, e.g. one to five packets of codeine based analgesics or 80 to $400 \mathrm{mg}$ of codeine and takes approximately $45 \mathrm{~min}$ to cook, sometimes less. Although other home-produced substances are not without harms, krokodil seems to be associated with particularly severe complications and ghastly health outcomes [10]. The severe morbidity associated with injecting krokodil is likely a function of the short half-life of the drug, dictating frequent injection, missing or inapt reactants, and incomplete synthesis, leaving large fractions of reactants and resulting in an extremely corrosive drug cocktail $[14,65]$.

The transmission of BBVs is a major health concern associated with any form of injecting drug use [16, 22]. The primary causes of BBV transmission are the collective use of injecting equipment (needle sharing) and sharing of liquefied drugs [98-101]. These behaviours are also important drivers of skin and soft tissue infections (SSTIs) around injection sites, affecting $10-30 \%$ of PWID [102-104] and associated with loss of venous access and intramuscular or subcutaneous injection
$[102,104,105]$. It has been documented that there is a high risk of BBV transmission amongst PWID, through the sharing not only of needles but also of other equipment used in the process. HIV and hepatitis $\mathrm{C}$ infection rates amongst PWID are extremely high in Russia, Ukraine, Georgia, and other fSU countries [106]. These first two countries are reported as the most affected by krokodil use [23].

Grund et al. [14] summarised the major concerns related to krokodil use, as reported in the literature and by PWID, such as skin irritations, ulcers, scalelike skin deformations that eventually turn green (like a crocodile skin) and black (necrotic), jaw osteonecrosis, thrombophlebitis, muscle damage, thyroid injury, inflammation of kidneys and the liver, endocrine complications, amputation of limbs and, ultimately, death [16, 18-20, 56, 107, 108]. Reportedly, limb amputations or jaw removals are often the only lifesaving intervention [20, 57, 108]. Reportedly, people who inject krokodil often present at medical services in the later stages of disease because they fear medical stigma and close ties between medical providers and law enforcement or other systems of social control, such as child protection agencies [14, 109-111].

Krokodil is not the only homemade substance to have severe physical complications. In recent years, several Eastern European countries have reported "Manganese Induced Parkinsonism" associated with injection of "boltushka" (homemade cathinone). First described as "Manganism", as early as 1837 [112], overexposure to manganese is a severe condition that can become manifest after only a few months of boltushka injecting, with symptoms of dysarthria, hypokinesia, dystonia, and damaged posture [113-115]. Boltushka synthesis includes the oxidation of (the precursor) with permanganate or "marganzovka", a commonly used disinfectant in Russia, in water [44]. During the reaction, Manganese (Mn) is released and toxic levels of remnants remain in the liquid drug. The rapid progression of Manganism amongst boltushka consumers $[115,116]$ points at short term, continuous exposure to perhaps extremely high concentrations of manganese. Although data are missing, we suggests that manganese concentrations in people who inject homemade (meth)cathinone may exceed levels amongst people affected by industrial pollution and perhaps even those of workers in the battery manufacturing and manganese processing industries, who, reportedly, are most at risk [117]. This is a serious concern for PWID, treatment providers, healthcare workers, and policy makers alike as the resulting Parkinsonism syndrome is not reversible [44]. Studies suggest Manganism related to (meth)cathinone injection amongst immigrants in Western Europe and in Canada [116]. Individuals 
have reported experiencing manganese toxicity from using MCAT (4-methylmethcathinone) [118] in online drug community forums [119].

Countries outside of Eastern Europe should be wellinformed about these grave public health concerns. A variety of opioid and stimulant syntheses are described in detail on the Internet, and the precursors and reactants are readily available. This may lead to such harmful substances emerging in unexpected settings. Indeed, traditional drug diffusion theory [120, 121] accounts poorly for the way in which new drug trends spread geographically, from one locality to another, and culturally, between different social groups or communities, and also how information about their risks is being shared. Emerging drug trends no longer necessarily commence in (cultural) capitals, harbour cities or along (physical) drug trading routes. Indeed, in the glocalised and Vernetzte twenty first century, iDrugs and new drug trends may emerge in any municipality, large or small, urban, or rural. Digitalisation of drug markets, immigration, and global travel may also be of significant influence [16].

Due to the adverse health issues associated with these homemade substances, governmental reaction is necessary so as to increase the regulation of over the counter and prescribed medications, and also to provide coordinated services such as counselling services, medical supports, wound and infection management, testing and support for HIV, outreach, and rehabilitation services for users of the substances [16, 20, 58, 65, 122-126]. Development of harm reduction tactics such as hygiene education, needle exchanges, bleach distribution, provision of filters, foil packs to try encourage users to reverse route of administration, provision of safer recipes for home-produced substances, treatment such as opiate substitution and antiretroviral therapy, and prevention programmes are vital [16, 44, 123-126]. Continuing research that will explore users' awareness of harms of homemade drugs, user practices, users' experiences of services, and trajectories of use are fundamental to informing harm reduction approaches $[14,16]$. Continued surveillance and monitoring at harm reduction programmes using internal data systems to monitor new trends is warranted.

\section{Conclusion}

Home-produced substances that replace illicit ones, such as heroin and amphetamines, are associated with many complex health issues and high levels of morbidity. This scoping review has presented extant literature on the topic and highlights how this issue is a growing and concerning public health imperative warranting drug user and online surveillance, targeted harm reduction and clinical responses.

\section{Endnotes}

"Screw," with reference to some of its less pleasurable side-effects.

"White".

"Chatterbox".

\section{Abbreviations}

ADHD: attention deficit hyperactivity disorder; ATS: amphetamine-type stimulant; BBV: blood borne virus; CACC: combination analgesics containing codeine; CCS: codeine-containing cough syrup; fSU: Former Soviet Union; GHB: gamma-hydroxybutyric acid; H2SO4: sulphuric acid; $\mathrm{KMnO} 4$ : potassium permanganate; MCAT: 4-methylmethcathinone (4-MMC); MDMA: 3,4methylenedioxymethamphetamine; MDPV: methylenedioxypyrovalerone; OTC: over the counter; PWID: people who inject drugs; SSTIs: skin and soft tissue infections; UNODC: United Nations Office on Drugs and Crime.

\section{Competing interests}

The authors declare that they have no competing interests.

\section{Authors' contributions}

EH was responsible for designing the study and writing the paper. MCVH was involved in the study design, critically reviewed the manuscript, and had full control, including final responsibility for the decision to submit the paper for publication. JPCG contributed to the manuscript by providing relevant data and studies, critically reviewing and editing several drafts. JMV contributed to the development of the review together with the writing and editing of the manuscript. All authors read and approved the final manuscript.

\section{Author details}

${ }^{1}$ School of Health Sciences, Waterford Institute of Technology, Waterford, Ireland. ${ }^{2}$ Department of Addictology, 1st Faculty of Medicine, Charles University, Prague, Czech Republic. ${ }^{3} \mathrm{CVO}$ - Addiction Research Centre, Utrecht, The Netherlands. ${ }^{4}$ Freudenthal Institute for Science and Mathematics Education, Utrecht University, Utrecht, The Netherlands. ${ }^{5}$ Centre for Public Health, Liverpool John Moores University, Liverpool, UK.

Received: 28 July 2015 Accepted: 24 March 2016

Published online: 19 April 2016

\section{References}

1. Grund JPC, Zábranský T, Irwin K, Heimer R. Stimulant use in Central and Eastern Europe: how recent social history shaped current drug consumption patterns. In: Pates R, Riley D, editors. Interventions for amphetamine misuse. Oxford: Wiley-Blackwell; 2009. p. 173-204.

2. Grund JPC. A Candle lit from both sides: the epidemic of HIV infection in Central and Eastern Europe. In: McElrath K, editor. HIV and AIDS: A global view. Westport, CT: Greenwood Press; 2002. p. 41-68.

3. Heimer R, Booth RE, Irwin KS, Merson MH. HIV and drug use in Eurasia. In: Twigg JL, editor. HIV/AIDS in Russia and Eurasia. Volume 2. Basingstoke, Hampshire, UK: Palgrave Macmillan; 2007.

4. Orlova AV. The Russian "war on drugs": a kinder, gentler approach? Probl Post Communism. 2009;56 Suppl 1:23-34.

5. Dehne KL, Grund JPC, Khodakevich L, Kobyshcha Y. The HIV/AIDS epidemic among drug injectors in Eastern Europe: patterns, trends and determinants. J Drug Issues. 1999;29 Suppl 4:729-76.

6. Rhodes T, Ball A, Stimson GV, Kobyshcha Y, Fitch C, Pokrovsky V, et al. HIV infection associated with drug injecting in the Newly Independent States, Eastern Europe: the social and economic context of epidemics. Addiction. 1999;94(9):1323-36.

7. Barnett T, Whiteside A, Khodakevich L, Kruglov Y, Steshenko V. The HIV/AIDS epidemic in Ukraine: its potential social and economic impact. Soc Sci Med. 2000;51 Suppl 9:1387-403.

8. Des Jarlais DC, Grund J-PC, Zadoretzky C, Milliken J, Friedmann P, Titus S, et al. HIV risk behaviour among participants of syringe exchange programmes in central/eastern Europe and Russia. Int J Drug Policy. 2002; 13:165-74.

9. Balakireva OM, Grund J-PC, Barendregt C, Rubanets $\mathrm{V}$, Ryabova MV, Volyk AM, Levchuk N, Meshcherina O, Bondar T. Risk and protective factors in the initiation of injecting drug use: report of a respondent driven sampling study and strategy paper on preventing the initiation of injecting drug use among 
vulnerable adolescents and young people. Kiev: UNICEF/UISR. [http://www. unicef.org/ukraine/3_HIV_injecting_drug_users_en.pdf]. Accessed 18 Mar 2013.

10. Booth RE, Lehman WEK, Latkin CA, Dvoryak S, Brewster JT, Royer MS, et al. Individual and network interventions with injection drug users in 5 Ukraine cities. Am J Public Health. 2011;101 Suppl 2:336-43.

11. Alcabes P, Grund JPC, Beniowski M, Bozek B, Kaciuba A, Zielinski A. Possible epidemic spread of HIV by syringe-based drug sharing in Poland: paradigm for the new AIDS frontier: 28 June - 3 July 1998. Geneva: 12th World AIDS Conference; 1998

12. Latypov AB. The Soviet doctor and the treatment of drug addiction: "a difficult and most ungracious task". Harm Reduct J. 2011:8:32.

13. Cone EJ. Ephemeral profiles of prescription drug and formulation tampering: evolving pseudoscience on the Internet. Drug Alcohol Depend. 2006;83 Suppl 1:31-9.

14. Grund JPC, Latypov AB, Harris M. Breaking worse: the emergence of krokodil and excessive injuries among people who inject drugs in Eurasia. Int J Drug Policy. 2013;24 Suppl 4:265-74.

15. Brandt SD, King LA, Evans-Brown M. The new drug phenomenon. Drug Test Anal. 2014;6(Suppl 7-8):587-97.

16. Van Hout MC. Kitchen chemistry: a scoping review of the diversionary use of pharmaceuticals for non-medicinal use and home production of drug solutions. Drug Test Anal. 2014;6(Suppl 7-8):778-87.

17. UNODC. World drug report 2013. Vienna: United Nations; 2013.

18. Azbel L, Dvoryak S, Altice FL. 'Krokodil' and what a long strange trip it's been. Int J Drug Policy. 2013;24 Suppl 4:275-80.

19. Gahr M, Freudenmann RW, Hiemke C, Gunst IM, Connemann BJ, SchonfeldtLecuona C. "Krokodil": revival of an old drug with new problems. Subst Use Misuse. 2012;47 Suppl 7:861-3.

20. Gahr M, Freudenmann RW, Hiemke C, Gunst IM, Connemann BJ, Schonfeldt-Lecuona C. Desomorphine goes "crocodile". J Addict Dis. 2012;31 Suppl 4:407-12.

21. Thekkemuriyi DV, John SG, Pilai U. "Krokodil" —a designer drug from across the Atlantic, with serious consequences. Am J Med. 2014;127 Suppl 3:1-2.

22. Zheluk A, Quinn C, Meylakhs P. Internet search and krokodil in the Russian federation: an infoveillance study. J Med Internet Res. 2014;16 Suppl 9, e212.

23. Alves EA, Grund JPC, Afonso CM, Netto AD, Carvalho F, Dinis-Oliveira RJ. The harmful chemistry behind krokodil (desomorphine) synthesis and mechanisms of toxicity. Forensic Sci Int. 2015:249:207-13.

24. Vearrier D, Greenberg MI, Ney Miller S, Okaneku JT, Haggerty DA. Methamphetamine: history, pathophysiology, adverse health effects, current trends, and hazards associated with the clandestine manufacture of methamphetamine. Dis Mon. 2012;28 Suppl 2:38-89.

25. Vernon A. Response to "one-pot" meth labs. Fire Eng. 2013;166 Suppl 11:79-82

26. UNODC. World drug report 2012. Vienna: United Nations Publication; 2012.

27. Arksey H, O'Malley L. Scoping studies: towards a methodological framework. Int J Soc Res Meth. 2005;8 Suppl 1:19-32.

28. Levac D, Colquhoun $\mathrm{H}, \mathrm{O}$ 'Brien KK. Scoping studies: advancing the methodology. Implement Sci. 2010;5 Suppl 1:69-78.

29. Daudt HM, van Mossel C, Scott S. Enhancing the scoping study methodology: a large, inter-professional team's experience with Arksey and O'Malley's framework. BMC Med Res Methodol. 2013;13:48.

30. Alter MJ, Kruszon-Moran D, Nainan OV, McQuillan GM, Gao F, Moyer LA, et al. The prevalence of hepatitis C virus infection in the United States 1988 through 1994. N Engl J Med. 1999;341 Suppl 8:556-62.

31. Hser YI, Hoffman V, Grella CE, Anglin MD. A 33-year follow-up of narcotics addicts. Arch Gen Psychiatry. 2001;58 Suppl 5:503-8.

32. Hser YI, Gelberg L, Hoffman V, Grella CE, McCarthy W, Anglin MD. Health conditions among aging narcotics addicts: medical examination results. J Behav Med. 2004;27 Suppl 6:607-22.

33. Hser Yl, Huang D. Trajectories of heroin addiction: growth mixture modelling results based on a 33-year follow-up study. Evaluation Rev. 2007; 31 Suppl 6:548-63.

34. UNODC. World drug report 2010. Vienna: United Nations Publication; 2010

35. Hutchings HA, Eccles R. The opioid agonist codeine and antagonist naltrexone do not affect voluntary suppression of capsaicin induced cough in healthy subjects. Eur Res J. 1994;7 Suppl 4:715-9.

36. Bhandari M, Bhandari A, Bhandari A. Recent updates on codeine. Pharm Methods. 2011;2 Suppl 1:3-8

37. Hou H, Yin S, Jia S, Hu S, Sun T, Chen Q, et al. Decreased striatal dopamine transporters in codeine-containing cough syrup abusers. Drug Alcohol Depend. 2011;118(Suppl 2-3):148-51.
38. Vree TB, van Dongen RT, Koopman-Kimenai PM. Codeine analgesia is due to codeine-6-glucuronide, not morphine. Int J Clin Pract. 2000; 54 Suppl 6:395-8.

39. Shek DT, Lam CM. Adolescent cough medicine abuse in Hong Kong: implications for the design of positive youth development programs in Hong Kong. Int J Adolesc Med Health. 2006;18 Suppl 3:493-503.

40. Yang Y, Yuan QY. Investigation and analysis on personalities of male-codeine phosphate addicts by MMPI. Chinese J Drug Abuse Prevent Treat. 2008;14:143-5.

41. Reed K, Bond A, Witton J, Cornish R, Hickman M, Strang J. The changing use of prescribed benzodiazepines and z-drugs and of overthe-counter codeine-containing products in England: a structured review of published english and international evidence and available data to inform consideration of the extent of dependence and harm. London: The National Addiction Centre, Kings College London; 2011

42. Van Hout MC. Nod and wave: an Internet study of the codeine intoxication phenomenon. Int J Drug Policy. 2015;26 Suppl 1:67-77.

43. World Health Organization (WHO). Disease control priorities related to mental, neurological, developmental and substance abuse disorders. Disease Control Priorities Project, Department of Mental Health and Substance Abuse. Geneva: WHO; 2006.

44. Chintalova-Dallas R, Case P, Kitsenko N, Lazzarine Z. Boltushka: homemade amphetamine-type stimulant and HIV risk in Odessa, Ukraine. Int J Drug Policy. 2009;20 Suppl 4:347-51.

45. Mackey S, Stewart JL, Connolly CG, Tapert SF, Paulus MP. A voxel-based morphometry study of young occasional users of amphetamine-type stimulants and cocaine. Drug Alcohol Depend. 2014;2014(135):104-11.

46. Berman SM, Kuczenski R, McCracken JT, London ED. Potential adverse effects of amphetamine treatment on brain and behavior: a review. Mol Psychiatry. 2009;14(2):123-42.

47. Substance Abuse and Mental Health Services Administration. Results from the 2010 national survey on drug use and health: summary of national findings. Rockville, MD: NSDUH Series H-41; 2011.

48. Tait RJ, McKetin R, Kay-Lambkin F, Bennett K, Tam A, Bennett A, et al. Breakingtheice: a protocol for a randomised controlled trial of an internetbased intervention addressing amphetamine-type stimulant use. BMC Psychiatry. 2012:12:67-75.

49. Colofax G, Santos GM, Chu P, Vittinghoff E, Pluddemann A, Kumar S, et al. Amphetamine-group substances and HIV. Lancet. 2010;376(9739):458-74.

50. UNODC. Patterns and trends of amphetamine-type stimulants and other drugs: challenges for Asia and the Pacific. Vienna: UNODC; 2010.

51. Griffiths P, Mravcik V, Lopez D, Klempova D. Quite a lot of smoke but very limited fire-the use of methamphetamine in Europe. Drug Alcohol Rev. 2008;27 Suppl 3:236-42

52. Booth RE. 'Krokodil' and other home-produced drugs for injection: a perspective from Ukraine. Int J Drug Policy. 2013;24 Suppl 4:277-8.

53. Grund JP. The eye of the needle: an ethno erpidemiological analysis of injecting drug use. In: Pates R, McBride A, Arnold K, editors. Injecting illicit drugs. Volume 8. 1st ed. London: Blackwell; 2006.

54. Zábranský T. Methamphetamine in the Czech Republic. J Drug Issues. 2007;37 Suppl 1:155-80.

55. EMCDDA. Perspectives on drugs. Health and social responses for methamphetamine users. EMCDDA: Lisbon; 2014.

56. Walker S. Krokodil: the drug that eats junkies. The Independent. [http:// www.independent.co.uk/news/world/europe/krokodil-the-drug-that-eatsjunkies-2300787.html]. Accessed 4 Jan 2013.

57. Shuster S. The curse of the crocodile: Russia's deadly designer drug. Time Magazine. [http://content.time.com/time/world/article/0,8599,2078355,00.html]. Accessed 4 Jan 2013

58. Skowronek R, Celiński R, Chowaniec C. "Crocodile"—-new dangerous designer drug of abuse from the East. Clin Toxicol (Phil). 2012;50 Suppl 4:269.

59. Aretha D. Methamphetamine and amphetamines. Ernslow: Berkeley Heights, NJ: 2005.

60. Barcal K, Schumacher JE, Dumchev K, Moroz LV. A situational picture of HIV/ AIDS and injection drug use in Vinnitsya, Ukraine. Harm Reduct J. 2005; 2 Suppl 1:16.

61. Varlibas F, Delipoyraz I, Yuksel G, Filiz G, Tireli H, Gecim NO. Neurotoxicity following chronic intravenous use of "Russian cocktail". Clin Toxicol (Phil). 2009:47 Suppl 2:157-60.

62. Lindblad KE. Bad news: people are taking krokodil in Norway. [http://www.vice.com/en_uk/read/krokodil-norway]. Accessed 19 Nov 2013 
63. Katselou M, Papoutsis I, Nikolaou P, Spiliopoulou C, Athanaselis S. A "Krokodil" emerges from the murky waters of addiction. Abuse trends of an old drug. Life Sci. 2014;102 Suppl 2:81-7.

64. Piralishvili G, Gamkrelidze I, Nikolaishvili N, Chavchanidze M. Needs assessment and treatment compliance at state opioid substitution treatment programmes in Georgia. Georgian Med News. 2013;214:8-32.

65. Harris M. The 'do-it-yourself' New Zealand injecting scene: implications for harm reduction. Int J Drug Policy. 2012;24 Suppl 4:281-3.

66. Der Spiegel. Todesdroge Krokodil erreicht Deutschland. [Death drugs crocodile reaches Germany]. [http://www.spiegel.de/panorama/justiz/russischer heroinersatz-todesdroge-krokodil-erreicht-deutschland-a-791273.html]. Accessed 18 Nov 2013.

67. Rowlands J, Kyriakos K. Sisa: is meth use the latest face of the catastrophe in Athens? [http://www.opendemocracy.net/can-europe-make-it/josephrowlands-kyriakos-klosidis/sisa-is-meth-use-latest-face-of-catastrophe-in-]. Accessed 27 Mar 2014

68. Miller A. Austerity's drug of choice. Sisa is destroying the lives of Athens's homeless people. [http://www.vice.com/en_uk/read/austeritys-drug-ofchoice-000757-v20n5]. Accessed 19 Nov 2013.

69. Wisselink DJ, Kuijpers WGT, Mol A. Kerncijfers Verslavingszorg 2013. Landelijk Alcohol en Drugs Informatie Systeem (LADIS). Houten: Stichting IVZ; 2014

70. van Gaalen S, de Bruin D, Grund J-PC. GHB overdose prevention among people who use GHB at home in the Netherlands and Belgium (2014-2015). An exploration of the characteristics associated with overdose and opportunities for risk reduction. Amsterdam: Mainline Foundation; 2015.

71. Booth RE, Lehman W, Kwiatkowski C, Brewster J, Sinitsyna L, Dvoryak S. Stimulant injectors in Ukraine: the next wave of the epidemic? AIDS Behav. 2008;12 Suppl 4:652-61.

72. Platt L, Rhodes T, Hickman M, Mikhailova L, Lisetsky K, Sarang A, et al. Changes in HIV prevalence and risk among new injecting drug users in a Russian city of high HIV prevalence. J Acquir Immune Defic Syndr. 2008;47 Suppl 5:623-31.

73. Zabransky T, Grund JPC, Latypov A, Otiashvili D, Stuikyte R, Scutelniciuc O. (2012) Harm reduction in central and Eastern Europe. In: Pates R, Riley D, editors. Harm reduction in substance use and high-risk behaviour: international policy and practice summaries. Volume 32. 5th ed. Oxford: Wiley Blackwell; 2012. p. 301-21.

74. Carlisle Maxwell J. Trends in the abuse of prescription drugs. Austin, Texas: The Gulf Coast Addiction Technology Transfer Center (GCATTC); 2006.

75. Lankenau SE, Teti M, Silva K, Jackson Bloom J, Harocopos A, Treese M. Initiation into prescription opioid misuse amongst young injection drug users. Int J Drug Policy. 2012;23(1):37-44.

76. Katz N, Dart RC, Bailey E, Trudeau J, Osgood E, Paillard F. Tampering with prescription opioids: nature and extent of the problem, health consequences, and solutions. Am J Drug Alcohol Abuse. 2011;37 Suppl 4:205-17.

77. UNODC. The non-medicinal use of prescription drugs. Policy direction issues. Discussion paper. Vienna: UNODC; 2011.

78. Fleming GF, McElnay JC, Hughes CM. The separation of codeine from nonprescription combination analgesic products. Subst Use Misuse. 2003;38 Suppl 9:1217-26.

79. Gordon SM, Forman RF, Siatkowski C. Knowledge and use of the internet as a source of controlled substances. J Subst Abuse Treat. 2006;30 Suppl 3:271-4.

80. Budman SH, Grimes Serrano JM, Butler SF. Can abuse deterrent formulations make a difference? Expectation and speculation. Harm Reduct J. 2009;6 Suppl 8:1-7.

81. Nielsen S, Barratt MJ. Prescription drug misuse: is technology friend or foe? Drug Alcohol Rev. 2009;28 Suppl 1:81-6.

82. Raffa RB, Pergolizzi JV. Opioid formulations designed to resist/deter abuse. Drugs. 2010;70 Suppl 13:1657-75

83. Romach MK, Schoedel KA, Sellers EM. Update on tamper resistant drug formulations. Drug Alcohol Depend. 2013;130:13.

84. EMCDDA. The Internet and drug markets. 2015. Summary of results from an EMCDDA Trendspotter study. LisbonL EMCDDA.

85. Dolliver DS. Evaluating drug trafficking on the Tor Network: Silk Road 2, the sequel. Int J Drug Policy. 2015;26:1113-23. Available online 14 Jan 2015 .

86. Konrad A. Feds say they've arrested 'dread pirate Roberts,' shut down his black market 'the Silk Road'. [http://www.forbes.com/sites/alexkonrad/2013/ 10/02/feds-shut-down-silk-road-owner-known-as-dread-pirate-robertsarrested]. Accessed 18 Mar 2015.
87. Barratt MJ, Ferris JA, Winstock AR. Use of Silk Road, the online drug marketplace, in the United Kingdom, Australia and the United States. Addiction. 2014;109 Suppl 5:774-83.

88. Davey Z, Schifano F, Corazza O, Deluca P. e-Psychonauts: conducting research in online drug forum communities. J Ment Health. 2012;21 Suppl 4:386-94.

89. Forsyth AJM. Virtually a drug scare: mephedrone and the impact of the Internet on drug news transmission. Int J Drug Policy. 2012;23 Suppl 3:198-209.

90. Van Hout MC, Bingham T. 'Surfing the Silk Road': a study of users' experiences. Int J Drug Policy. 2013;24(6):524-9.

91. Van Hout MC, Bingham T. Responsible vendors, intelligent consumers: Silk Road, the online revolution in drug trading. Int J Drug Policy. 2014;25(2): 183-9.

92. Chiauzzi E, DasMahapatra P, Lobo K, Barratt MJ. Participatory research with an online drug forum: a survey of user characteristics, information sharing, and harm reduction views. Subst Use Misuse. 2013;48 Suppl 8:661-70.

93. Móró L, Rácz J. Online drug user-led harm reduction in Hungary: a review of "Daath". Harm Reduct J. 2013;10:18.

94. Soussan C, Kjellgren A. Harm reduction and knowledge exchange-a qualitative analysis of drug-related internet discussion forums. Harm Reduct J. 2014;11:25.

95. Soussan C, Kjellgren A. "Chasing the high"-experiences of ethylphenidate as described on international Internet forums. Subst Abuse. 2015;9:9-16.

96. Van Hout MC, Hearne E. 'Word of mouse': indigenous harm reduction and online consumerism of the synthetic compound methoxphenidine. J Psychoact Drugs. 2014;47 Suppl 1:30-41.

97. EHRN. Young people and injecting drug use in selected countries of Central and Eastern Europe. [http://www.harm-reduction.org/library/young-peopleinjecting-drug-use-selected-countries-central-andeastern-europe]. Accessed 9 Nov 2013.

98. Clatts MC, Heimer R, Abdala N, Goldsamt L, Sotheran J, Anderson KT, et al. HIV-1 transmission in injection paraphernalia: heating drug solutions may inactivate HIV-1. J Acquir Immune Defic Syndr. 1999;22(2):194-9.

99. Grund JPC, Kaplan CD, Adriaans NFP, Blanken P. Drug sharing and HIV transmission risks: the practice of "frontloading" in the Dutch injecting drug user population. J Psychoact Drugs. 1991;23:1-10.

100. Dumchev KV, Soldyshev R, Qian HZ, Zezyulin OO, Chandler SD, Slobodyanyuk $P$, et al. HIV and hepatitis $C$ virus infections among hanka injection drug users in central Ukraine: a cross-sectional survey. Harm Reduction Journal. 2009;6:23.

101. Hagan H, Thiede H, Weiss NS, Hopkins SG, Duchin JS, Alexander ER. Sharing of drug preparation equipment as a risk factor for hepatitis C. Am J Public Health. 2001;91(1):42-6.

102. Binswanger IA, Kral AH, Bluthenthal RN, Rybold DJ, Edlin BR. High prevalence of abscesses and cellulitis among community-recruited injection drug users in San Francisco. Clin Infect Dis. 2000;30:579-81.

103. Murphy EL, DeVita D, Liu H, Vittinghoff E, Leung P, Ciccarone DH, et al. Risk factors for skin and soft-tissue abscesses among injection drug users: a case-control study. Clin Infect Dis. 2001;33:35-40.

104. Ciccarone D, Bourgois P. Explaining the geographical variation of HIV among injection drug users in the United States. Subst Use Misuse. 2003; 38:2049-63.

105. Lloyd-Smith E, Wood E, Zhang R, Tyndall MW, Montaner JS, Kerr T. Risk factors for developing a cutaneous injection-related infection among injection drug users: a cohort study. BMC Pub Health. 2008;8:405.

106. UNAIDS. The GAP report 2014: people who inject drugs. Geneva: UNAIDS; 2014.

107. Asaeva AV, Ocheret D, Fayziev Zh. Russia: New trends in drug use lead to severe health consequences and death among IDUs: 3-7 April 2011; 22nd international conference on the reduction of drug related harm, Beirut, 2011.

108. Poghosyan YM, Hakobyan KA, Poghosyan AY, Avetisyan EK. Surgical treatment of jaw osteonecrosis in "Krokodil" drug addicted patients. J Cranio-Maxillo- Fac Surg. 2014;42:1639-43.

109. Orekhovsky V, Calzavara L, Yakovlev A, Nikitina T, Volkova G, Michalchenko M, Saldanha V. Fuelling HIV epidemic in Russia: the stigma of IDU and HIV and its impact on treatment access and testing. In: Poster presentation, The XIV international AIDS conference: 7-12 July, 2002; Barcelona: Spain; 2002.

110. Elovich R, Drucker E. On drug treatment and social control: Russian narcology's great leap backwards. Harm Reduct J. 2008:5:23. 
111. Wolfe D, Carrieri MP, Shepard D. Treatment and care for injecting drug users with HIV infection: a review of barriers and ways forward. Lancet. 2010;376 Suppl 9738:355-66.

112. Couper J. Sur les effets du peroxide de manganèse. Journal de chimie médicale, de pharmacie et de toxicologie. 1873;3:223-5.

113. Crossgrove J, Zheng W. Manganese toxicity upon overexposure. NMR Biomed. 2004;17:544-53.

114. Lucchini RG, Martin CJ, Doney BC. From manganism to manganese-induced parkinsonism: a conceptual model based on the evolution of exposure. Neuromolecular Med. 2009;11(4):311-21. Jan [cited 2015 Apr 1]. Available from: http://www.ncbi.nlm.nih.gov/pubmed/20012385.

115. Sikk K, Haldre S, Aquilonius SM, Taba P. Manganese-induced parkinsonism due to ephedrone abuse. Parkinsons Dis. 2011;4:1-8.

116. de Bie RMA, Gladstone RM, Strafella AP, Ko JH, Lang AE. Manganeseinduced parkinsonism associated with methcathinone (ephedrone) abuse. Arch Neurol. 2007;64(6):886-9.

117. Lucchini R, Selis L, Folli D, Apostoli P, Mutti A, Vanoni O, et al. Neurobehavioral effects of manganese in workers from a ferroalloy plant after temporary cessation of exposure. Scand J Work Environ Health. 1995; 21 Suppl 2:143-9.

118. Papanti D, Grund J-P, Francesconi F, Orsolini L, Schifano F. (New) Glocal syndremics: the 'M-cat' tale. Res Advances Psychiatry. 2014;1 Suppl 1:27.

119. Bluelight. Manganese poisoning from ephedrone (MCAT). [http://bluelight. org/vb/archive/index.php/t-665468.html]. Accessed 6 Apr 2014.

120. Oldenburg BF, Hardcastle DM, Kok G. Diffusion of innovations. In: Glanz K, Lewis FM, Rimer B, editors. Health behavior and health education: theory, research and practice. 2nd ed. San Francisco: Jossey-Bass; 1997. p. 207-86.

121. Ferrence R. Diffusion theory and drug use. Addiction. 2001;96 Suppl 1:165-73.

122. Mathers BM, Degenhardt L, Ali H, Wiessing L, Hickman M, Mattick RP, et al. HIV prevention, treatment, and care services for people who inject drugs: a systematic review of global, regional, and national coverage. Lancet. 2010; 375:1014.

123. Pizzey R, Hunt N. Distributing foil from needle and syringe programmes (NSPs) to promote transitions from heroin injecting to chasing: an evaluation. Harm Reduct J. 2008:5:24.

124. Bojko MJ, Dvoriak S, Altice FL. At the crossroads: HIV prevention and treatment for people who inject drugs in Ukraine. Addiction. 2013;108(10): $1697-9$

125. Hedrich D, Kerr T, Dubois-Arber F. Drug consumption facilities in Europe and beyond. In: Rhodes T, Hendrich D, editors. Harm reduction: evidence, impacts and challenges. Luxembourg: European Monitoring Centre for Drugs and Drug Addiction (EMCDDA), Scientific Monograph, Office of the European Union; 2010

126. Alistar SS, Owens DK, Brandeau ML. Effectiveness and cost effectiveness of expanding harm reduction and antiretroviral therapy in a mixed HIV epidemic: a modeling analysis for Ukraine. PLoS Med. 2011;8, e1000423.

\section{Submit your next manuscript to BioMed Central and we will help you at every step:}

- We accept pre-submission inquiries

- Our selector tool helps you to find the most relevant journal

- We provide round the clock customer support

- Convenient online submission

- Thorough peer review

- Inclusion in PubMed and all major indexing services

- Maximum visibility for your research

Submit your manuscript at www.biomedcentral.com/submit

) Biomed Central 